\title{
Editorial: Are They Listening? \\ Policymakers and Their Role in Public Education
}

\author{
Abbie R. Strunc \\ Guest Editor \\ astrunc@tamut.edu \\ Texas A\&M University-Texarkana \\ College of Arts, Sciences and Education \\ Texarkana, TX, USA
}

In the United States the policy making process claims to be a cyclical process which drives politicians, dictates policies drafted, and legislation ultimately passed. The process begins with the people bringing issues, ideas, and concerns to the attention of the news media, advocacy groups, grassroots organizations, or interest groups (Edwards \& Wattenberg 2018). Ideally these groups connect the concerns of the people to elected officials and/ or courts who respond by creating policies which address these concerns. This is an over-simplified ideal. The reality of policymaking is messy, partisan, and the results frequently fail to address the concerns of the public, or create more unintended consequences than solve problems. Public education is an area of concern most familiar with unintended consequences.

In the 1980s American president Ronald Reagan drafted educational policy which diverted funds from local control to state governments, increased state-level staffing positions, and decreased federal funds for public education by half (Clabaugh 2004). The Regan administration also ushered in the business model of education with the 1983 report, A Nation at Risk: The Imperative for Educational Reform. The document, produced by the U.S. Department of Education, created concern that the United States education system lagged behind their international counterparts. In response to the public education "crisis" policymakers promoted vouchers and tax credits (Strauss 2018). In addition, the emphasis of education shifted quickly to "the business model of education [which proves] learning in much the same way that businesses report proof of success through profits. In this model, student learning is treated as a commodity measured by results [o]n examinations" (Strunc \& King 2017, p 93). Publicly, this 
new model of education intended to improve public schools through the subsequent reforms (Strauss 2018). Despite the promised gains, and the continued passage of educational policies in successive administrations, the disparity of educational experience and outcomes persist in American education (Howard 2020).

This special issue of Research in Educational Policy and Management examines the impact and unintended consequences of federal, state, and local educational policies. In the first article of the issue, Van Overschelde and Piatt examine the teaching out-of-field allowance in the Every Student Succeeds Act. This policy intended to increase local control over effective teaching, however the authors discover that rather than closing the achievement gap, as was the intention, the high rates of out-of-field teaching are likely contributing to educational disparity. Palmer and Witanapatirana consider local school district policies to search for deficit thinking in "district of innovation" plans posted on district websites. The intent of these plans is to provide flexibility and choice for school districts, but what biases are present in district solutions? Are those biases overt?

Although the focus of the issue centers on unintended consequences, Wilcox offers a critical ethnography and critical discourse analysis to argue that not all consequences of policies are unintentional, but a smaller piece of a system structured to conform to systematic injustices imbedded within policies, based upon preconceived stereotypes.

Dickison considers the impact of policies funding public universities and how tuition deregulation might have negatively impacted public institutions. Did the de-regulation of tuition by the state legislature indicate a noticeable change in tuition? What are the implications for the opportunity to obtain public higher education?

Finally, the issue concludes as Timberlake examines the discriminatory construct of "ableism" found in three educational policies. At first consideration, ableism may not appear to discriminate, but the unintended consequences isolate students with disabilities. The policies created to be inclusive, instead marginalize the very students the policies were drafted to protect.

Examining educational policy continues to be important work for educational stakeholders. Policy makers continue to draft policies which produce challenges for students, educators, and educational leaders. It is imperative that these policies be studied and monitored so that schools benefit, student learning is enhanced, and thus a concentrated effort to close the achievement gap can begin. 


\section{REFERENCES}

Clabaugh, G. (2004). The Educational Legacy of Ronald Reagan. Educational Horizons, 82(4), 256-259. Retrieved June 1, 2020, from www.jstor.org/stable/42926508

Edwards, G.C. and Wattenberg, M.P. (2018). Government in America: People, politics, and policy. Pearson: New York, NY.

Howard, T.C. (2020). Why Race and Culture Matter in Schools: Closing the Achievement Gap in America's Classrooms, $2^{\text {nd }}$ Edition. Teachers College Press: New York, NY.

Strauss, V. (2018, April 26). 'A Nation at Risk' demanded education reform 35 years ago. Here's how it's been bungled ever since. The Washington Post. Retrieved from thewashingtonpost.com

Strunc, A. and King, K.M. (2017). Politics and the citizenship curriculum: A critical discourse analysis of the Texas government standards. Critical Approaches to Discourse Analysis across Disciplines, 9 (1): $91-112$. 